January 2015

\title{
"We're Cool" Statements after Omnicare: Securities Fraud Suits for Failures to Comply with the Law
}

James D. Cox

Duke Law School

\section{Recommended Citation}

James D. Cox, "We're Cool" Statements after Omnicare: Securities Fraud Suits for Failures to Comply with the Law, 68 SMU L. REV. 715 (2015)

https://scholar.smu.edu/smulr/vol68/iss3/13

This Tribute is brought to you for free and open access by the Law Journals at SMU Scholar. It has been accepted for inclusion in SMU Law Review by an authorized administrator of SMU Scholar. For more information, please visit http://digitalrepository.smu.edu. 


\title{
"We're CoOl" Statements AFter OMNicare: SECURITIES Fraud Suits FOR FAILURES TO COMPLY WITH THE LAW
}

James D. Cox*

\begin{abstract}
J UST as there was much celebration in Munchkin Land when Dorothy's house landed on the Wicked Witch of the East, so have securities law academics, whether pro-plaintiff or pro-defendant, celebrated the arrival of Omnicare Inc. v. Laborers District Council Construction Industry Pension Fund. ${ }^{1}$ The cause for this celebration is that Omnicare Inc. lands squarely on Virginia Bankshares, Inc. v. Sandberg, ${ }^{2}$ the Supreme Court's earlier, opaque approach for treatment of the materiality of opinion statements. In Virginia Bankshares, the Supreme Court quickly concluded shareholders would attach significance to the board of directors' statement that the cash-out merger price was "fair" and "high" so that the statement met the materiality standard, but emphasized there was another, more perplexing, issue: whether such an opinion statement was a statement of fact. On this question, Virginia Bankshares' formulation is hopelessly ambiguous except for the rather clear implication arising out of the record before the Court that opinion statements are statements of facts when there is before the defendant objective evidence in direct conflict with the professed opinion. ${ }^{3}$ Absent conflicting objective evidence, the opinion statement is not a "fact" but a non-actionable misrepresentation of the defendant's belief or motive. ${ }^{4}$

The preceding summary of Virginia Bankshares does not do justice to the turgid quality of Justice Souter's reasoning of what separates actionable from non-actionable opinion statements. As a result, Virginia Bankshares is a stimulating analytical exercise, but one steeped in nuance. Moreover, Virginia Bankshares' focus on what is a fact, rather than the
\end{abstract}

* Brainerd Currie Professor of Law, Duke University. The author is grateful for the outstanding research assistance of Mr. Jeremy Bethel in preparing this article.

1. Omnicare Inc. v. Laborers Dist. Council Constr. Indus. Pension Fund, $135 \mathrm{~S}$. Ct. 1318 (2015).

2. Va. Bankshares v. Sandberg, 501 U.S. 1083, 1091-99 (1991).

3. In Virginia Bankshares the board of directors was aware that the fair market value of the firm's assets was substantially greater than the book value on which the "high" and "fair" statements were based. Also, the financial consultant advising the board believed the firm's value translated to about $\$ 60$ a share although the price being supported by the board with its opinion was \$42. Id. at 1099 .

4. Id. at 1096. 
materiality of what was communicated, appears at odds with a basic tenet of the securities laws, namely providing information material to investors and not on the forensic qualities of the information within the defendant's possession. As developed below, Omnicare Inc. returns the focus to the traditional orientation of the information's significance to the investor.

\section{IMPLICATIONS OF OMNICARE INC.}

Omnicare Inc.'s contribution, as examined below, is far reaching as it provides an understandable, indeed conventional vis-à-vis the common law, approach to assessing whether opinion statements as well as a wide range of other statements are misleading. Moreover, Omnicare Inc. harbors the strong potential to dramatically change existing approaches to how we view an alleged misrepresentation under the federal securities laws.

In a registration statement for its public offering, Omnicare stated it "believed" its various contracts were "in compliance with applicable federal and state laws" and "legally and economically valid arrangements." Subsequent to the public offering, several federal government enforcement suits were initiated against Omnicare, alleging that various aspects of its contractual relationships and arrangements violated multiple provisions of federal health care laws. The plaintiff pension funds that purchased shares in the registered offering sued under Section 11 of the Securities Act, alleging that the opinion statements were materially misleading. Because securities issuers that commit a material misrepresentation in their registration statement have absolute liability under Section 11 of the Securities Act, the complaint did not allege awareness on the part of Omnicare of facts inconsistent with the professed opinion of compliance with the law. The complaint's failure to allege such awareness clashed with the formulation in Virginia Bankshares. The allegations in Omnicare therefore posed two distinct questions: who has the burden of establishing the existence of objective facts contrary to the stated opinion of compliance with the law ${ }^{5}$ and whether this showing must be accompanied by evidence of knowledge of such conflicting evidence by Omnicare officials. ${ }^{6}$ Because Section 11 imposes strict liability on a security's issuer, Virginia Bankshares' orthodoxy of placing both these burdens on the plaintiff meshes poorly with the absolute liability regime housed in Section 11 . At the same time, Virginia Bankshares clearly requires objective

5. The Sixth Circuit held that though the plaintiffs did not have to establish that Omnicare officials knew their belief was false, the funds were required to allege that the professed beliefs were "objectively false." Ind. State Dist. Council of Laborers \& HOD Carriers Pension \& Welfare Fund v. Omnicare, Inc., 719 F.3d 498, 506-07 (6th Cir. 2013).

6. See Ind. State Dist. Council of Laborers \& HOD Carriers Pension \& Welfare Fund v. Omnicare, Inc., 2012 U.S. Dist. LEXIS 17526 (E.D. Ky. Feb. 13, 2012) (granting dismissal of case because the complaint failed to allege "the company's officers knew they were violating the law"). 
facts before the defendant that are inconsistent with the opinion as a precondition to that opinion statement being a fact.

A key step in Justice Kagan's majority opinion in Omnicare Inc. is recognizing that Section 11, similar to other disclosure provisions, focuses on what is stated as well as what is omitted from what is stated. Thus, her approach to opinion statements is consistent with the rich body of law that has developed surrounding statements held to be misleading because they constitute a half-truth. ${ }^{7}$ She observes "a reasonable investor may, depending on the circumstances, understand an opinion statement to convey facts about how the speaker has formed the opinion... [ [I]f the real facts are otherwise, but not provided, the opinion statement will mislead its audience." Because the securities laws, and Section 11 expressly, condemn not only what is materially misstated but also what is materially omitted, Omnicare Inc. was able to focus on whether facts related to the opinion needed to be disclosed to prevent the opinion statement from being misleading.

[A]n investor cannot state a claim by alleging only that an opinion was wrong; the complaint must as well call into question the issuer's basis for offering the opinion. ... [A] cause of action [exists] only when an issuer's failure to include a material fact has rendered a published statement misleading. . . . The investor must identify particular (and material) facts going to the basis for the issuer's opinion - facts about the inquiry the issuer did or did not conduct or the knowledge it did or did not have - whose omission makes the opinion statement at issue misleading to a reasonable person reading the statement fairly and in context. ${ }^{8}$

Because Omnicare's opinion statements focused on its purported compliance with the law, the opinion applied the above formulation to such statements:

Consider an unadorned statement of opinion about legal compliance: "We believe our conduct is lawful." If the issuer makes that statement without having consulted a lawyer, it could be misleadingly incomplete ... [A]n investor, although recognizing that legal opinions can prove wrong in the end, still likely expects such an assertion to rest on some meaningful legal inquiry . . . Similarly, if the issuer made the statement in the face of its lawyers' contrary advice, or with knowledge that the Federal Government was taking the opposite view, the investor again has cause to complain: He expects not just that the issuer believes the opinion . . . but that it fairly aligns with the information in the issuer's possession at the time. ${ }^{9}$

The investor referenced above is the objectively qualified investor. Thus, the formulation for opinion statements is the orthodox half-truth doctrine where, even under the strict liability standard of Section 11, the burden is

7. Omnicare Inc. v. Laborers Dist. Council Constr. Indus. Pension Fund, 135 S. Ct. $1318,1330-31$ (2015).

8. Id. at 1332 .

9. Id. at $1328-29$. 
upon plaintiff to establish under the totality of the circumstances that omitted facts were necessary to disclose in order to render the opinion statement not materially misleading. In the absolute liability context, such as Omnicare Inc., the preceding formulation, while requiring the plaintiff to allege what facts were not disclosed that were needed to render what was said not misleading, the plaintiff is not required to further establish that the issuer was aware of those facts. At the same time, whereas Virginia Bankshares conceded that directors' opinions of the fairness of merger terms are always material, after Omnicare Inc. this concedes too much: the plaintiff must establish the material falsity of that opinion. ${ }^{10}$

A final point posed by Omnicare Inc. is whether it weakens the doctrinaire bulwark that lower courts have developed that generalized statements of optimism, commonly referred to as puffery, are not material. For example, consider J.P. Morgan's touting that the company's "risk management processes ... are highly disciplined," a claim it made on the cusp of the recent financial crisis that nearly terminated the firm because of excessive exposure to risk. Before Omnicare Inc., the court had ample precedent to support dismissal of the suit on the grounds the claim was non-actionable puffery. ${ }^{11}$ After Omnicare Inc., the outcome of such a suit is surrounded by a good deal of uncertainty since J.P. Morgan's statement is not distinguishable from Omnicare Inc.'s statement, "[w]e believe our contract arrangements ... are in compliance with applicable federal and state laws." 12 Each are generalized statements of opinion, and each point to a body of facts and principles upon which investors can be expected to believe management premised its opinion. Moreover, each appears potentially actionable under Omnicare Inc.'s formulation of considering how the statement is likely understood by the reasonable investor so that the plaintiff can challenge the statement as a half-truth based on facts before the speaker that were materially inconsistent with the professed optimistic statement. In the end, puffery is but an optimistic opinion that the investor can expect the speaker has some factual basis. Absent that factual basis, the opinion is actionable.

10. Consider here Omnicare Inc.'s further qualification:

An opinion statement, however, is not necessarily misleading when an issuer knows, but fails to disclose, some fact cutting the other way. Reasonable investors understand that opinions sometimes rest on a weighing of competing facts; indeed, the presence of such facts is one reason why an issuer may frame a statement as an opinion, thus conveying uncertainty ... Suppose, for example, that in stating an opinion about legal compliance, the issuer did not disclose that a single junior attorney expressed doubts about a practice's legality, when six of his more senior colleagues gave a stamp of approval. That omission would not make the statement of opinion misleading, even if the minority position ultimately proved correct: A reasonable investor does not expect that every fact known to an issuer supports its opinion statement.

Id. at 1329 (emphasis in original).

11. ECA \& Local 134 IBEW Joint Pension Trust of Chi. v. J.P. Morgan Chase Co., 553 F.3d 187, 195 (2d Cir. 2009).

12. Omnicare, Inc., $135 \mathrm{~S}$. Ct. at 1323. 
Because managers of public firms inevitably enjoy much better information about the firm than do investors, the insights, observations, comments, etc. by managers about matters uniquely within management's sphere of knowledge can always be expected to pique the interest of investors. Certainly risk management by financial institutions has grown in significance to investors following the recent financial crisis so that statements such as those by J.P. Morgan are likely today to be of even greater significance to investors than they were when J.P. Morgan first made its claim. Investor interest in management stewardship obviously extends beyond just financial risk; it includes how regulatory requirements that define the firm's environment, and hence its operations and future, are impacting the firm's on-going operations. A clear disclosure requirement on these points appears in the SEC's management discussion and analysis provision that calls for disclosure in documents filed with the SEC of any existing trend or uncertainty management reasonably expects will have a material impact on the firm's operations. ${ }^{13}$ As one recent court reasoned, the failure to satisfy this requirement implies that management is not aware of any such condition or circumstance. ${ }^{14}$ Observe that the disclosure elicited by this provision is exactly the kind of statement now covered by Omnicare Inc. and can therefore include disclosures of philosophy, policies, and practices employed by managers in their operation and oversight of the firm. But disclosure of such matters is inherently sensitive, not only because they can upon disclosure erode competitive advantages, but also because some firms do pursue unreasonable or unlawful means to compete for revenues so that shining a light on their antisocial practices invites prosecution for the resulting wrongdoing. It is on this point - the quality of management's stewardship-that we can expect to see a significant fissure develop in Omnicare Inc.'s wake from the weaknesses of state fiduciary law to discipline unreasonable or unlawful corporate stewardship.

\section{LEGAL COMPLIANCE AND THE TIMIDITY OF STATE LAW}

In re Caremark International Inc. Derivative Litigation ${ }^{15}$ is among the most significant corporate decisions because it provided powerful legal compulsion for boards of directors to establish, maintain, and monitor legal compliance programs. The task before Chancellor Allen was uninspiring and non-controversial-approving the settlement of a questionably initiated derivative suit alleging the corporation's board of directors failed to provide appropriate oversight of the healthcare firm. Caremark had incurred substantial costs and a significant fine in connection with its settlement of a government enforcement action claiming that Caremark

13. Item 303, SEC Regulation S-K., 17 C.F.R. \& 229.303(a)(3)(ii) \& (b) (2015).

14. Stratte-McClure v. Morgan Stanley, 776 F.3d 94, 102 (2d Cir. 2015). Contra In re NVIDIA Corp. Sec. Litig., 768 F.3d 1046, 1056-57 (9th Cir. 2014).

15. In re Caremark Int'l Inc. Deriv. Litig., 698 A.2d 959, 967-70 (Del. Ch. 1996). 
had over the years systematically provided kickbacks and other rewards to hospitals and doctors in return for their directing business to Caremark. The parasitic derivative suit followed the government action; the derivative suit plaintiffs agreed to settle in return for Caremark agreeing to modest governance therapeutics to justify the sought-for fee award. As uninspiring as were the terms of the settlement, Chancellor Allen used the occasion to enshrine in the directors' duty of good faith an affirmative obligation to install, maintain, and monitor legal compliance programs. Chancellor Allen's dicta that the directors' duty of good faith can be violated if they have a "sustained and systematic failure" to establish and exercise reasonable oversight of a legal compliance system added state law fiduciary obligations to existing forces compelling legal compliance programs. Prior to the decision, prudent companies considered compliance programs a necessary appendage of best governance practices and a valuable factor considered by prosecutors and courts in considering sanctions to be imposed for corporate misconduct. These considerations became overwhelming following Caremark as personal liability was now possible for failure to install, maintain, and enforce law compliance programs. Indeed, such law compliance systems quickly became institutionalized as a cornerstone of good governance devices. ${ }^{16}$

Caremark's clarion call, when joined with the growing impact of the U.S. Sentencing Guidelines for Business Organizations that favor defendants with well-crafted and deployed compliance programs, not only made compliance programs ubiquitous but also heightened investor and shareholder interest in corporations complying with the law. In spite of this heightened interest, the actual number of suits initiated for alleged breach of fiduciary duty for alleged corporate failure to comply with the law is extremely small and the success rate for such suits is quite low. Among the dramatic successes is In re Abbott Laboratories Derivative Shareholder Litigation, ${ }^{17}$ where the Seventh Circuit sustained a suit's continuance in the face of allegations that over a six-year period the corporation had received several FDA warnings, some of which reached the board of directors, that ultimately led to a significant fine and the destruction of millions of dollars of inventory. ${ }^{18}$

Nonetheless, the challenges facing such state law actions are formidable. Caremark demands a substantial departure on the part of the board of directors-"a sustained and systematic failure" to be precise. Thus, a suit involving one of the most fundamental breakdowns in monitoring any firm's operations, that of Citigroup Inc. in the most recent financial

16. ABA, Corporate Director's Guidebook, at 33 (6th ed. 2015). 2003).

17. In re Abbott Labs. Derivative S'holders Litig., 325 F.3d 795, 802, 811 (7th Cir.

18. See also Rich ex rel. Fuqi Intern., Inc. v. Yu Kwai Chong, 66 A.3d 963, 968, 984, 986 (Del. Ch. 2013) (approving suit involving accounting system acknowledged by the firm to be so inadequate that it produced $\$ 130$ million in accounting errors and caused Nasdaq to threaten firm with delisting); In Re Am. Int'l Grp., Inc., 965 A.2d 763, 774 (Del. Ch. 2009) (sustaining complaint alleging firm engaged in a criminal enterprise that was greatly facilitated by substantial weaknesses in internal controls). 
crisis, was dismissed due to the high presumption of propriety accorded the action of independent directors. In re Citigroup Inc. Shareholder Derivative Litigation ${ }^{19}$ arose after the near bankruptcy of Citigroup due to its large exposure to the subprime lending markets. The suit focused on multiple "red flags," such as an economist's forecast that a speculative housing bubble was nearing its end, that a leading subprime lender was closing 229 of its offices, that another lender had filed for bankruptcy, that analysts were downgrading subprime mortgages, and that another lender had warned that there were increasing subprime delinquencies.

[The "red flags"] amount to little more than portions of public documents that reflected the worsening conditions in the subprime mortgage market and in the economy generally. Plaintiffs fail to plead "particularized facts suggesting that the Board was presented with 'red flags' alerting it to potential misconduct"... [The plaintiffs] repeatedly make the conclusory allegation that the defendants have breached their duty of oversight, but nowhere do [they] adequately explain what the director defendants actually did or failed to do that would constitute such a violation. Even while admitting that $\mathrm{Ci}$ tigroup had a risk monitoring system in place, plaintiffs seem to conclude that, because the director defendants . . . were charged with monitoring Citigroup's risk, then they must be found liable because Citigroup experienced losses as a result of exposure to the subprime mortgage market. The only factual support plaintiffs provide for this conclusion are "red flags" that actually amount to nothing more than signs of continuing deterioration in the subprime mortgage market. These types of conclusory allegations are exactly the kind of allegation that do not state a claim for relief under Caremark. ${ }^{20}$

The above treatment of Caremark is especially troubling in Delaware. Unlike other corporate jurisdictions, Delaware removes the presumption of the business judgment rule upon the showing of breaching conduct with the effect that the plaintiff is not burdened with establishing how the breach proximately harmed the corporation or its shareholders. ${ }^{21}$ To be sure, the plaintiff could easily have alleged that directors responding reasonably to the red flags could have at least inquired whether, in light of the developments captured in the red flags, taking on new exposures to subprime mortgages was prudent and whether reducing existing exposures was desirable. Under the Delaware approach to causation, defendants would bear the burden of exploring whether action on their part would in fact have mitigated the significant losses ultimately suffered by Citigroup. Moreover, there does not appear any particular policy reason why Caremark should be cabined to illegal misconduct. To be sure, Caremark sprang forth from illegal misconduct and part of the justification advanced by Chancellor Allen was the impact of the U.S. Criminal Sentencing Guidelines. But behind Caremark is a strong belief that direc-

19. In re Citigroup Inc. S'holder Derivative Litig., 964 A.2d 106, 111 (Del. Ch. 2009).

20. Id. at $129-30$.

21. Cede \& Co. v. Technicolor, Inc., 634 A.2d 345, 361 (Del. 1993). 
tors are monitors and thus need to install information systems to reduce crime but also to protect the financial interest of the corporation and shareholders. Corporations such as Citibank would be woefully shortsighted were surveillance systems installed only to monitor tellers to deter embezzlement but not monitor whether the business climate exposed the corporation to potential catastrophic losses.

Further impediment to such law compliance suits is the broad adoption of immunity shields whereby a provision in a corporation's articles of incorporation shield directors from liability for damages absent knowing misconduct by the directors. ${ }^{22}$ In the face of pervasive immunity shields, it is not possible to recover from directors for their failure to reasonably monitor management and business practices that cause substantial loss to the corporation. This indeed is the result reached in Citigroup where the clarion red flags were insufficient to move the alleged director misconduct beyond the immunity shield.

But the ultimate bulwark for directors against Caremark-based claims is the demand requirement that conditions pursuit of a derivative suit on the suit's plaintiff overcoming the board's unsurprising reluctance to approve a suit against itself. In broad overview, a growing number of states condition the derivative suit's continuance on the presiding court finding that the suit is in the corporation's interest. This determination in law compliance cases tilts favorably toward the board of directors, the very parties alleged to be at the heart of the breach, because the directors are deemed sufficiently independent in rendering an opinion regarding the corporation's interest served by the suit. The bias is even stronger in the more common demand-required jurisdictions, such as Delaware. Indeed, the issue before the Delaware court in Citigroup was whether a demand on the board could be excused; the court held the suit must be dismissed for failure to make a demand on the board. Thus, we can see that Caremark is important, it nudges directors toward better practices with respect to oversight of compliance programs, but enforcement occurs by social norms to pursue the right course, not by a substantial fear of liability for doing the wrong thing.

Federal securities litigation has, however, moved into the vacuum left by state law. As reviewed in the next section, over the last few years there has been a good deal of litigation under the antifraud provision, similar to that in Omnicare Inc., which focused on disclosures that projected a misleading report of the management's compliance with the law so that the overall quality of the firm's earnings were misrepresented.

\section{DISCIPLINING POOR STEWARDS UNDER THE SECURITIES LAWS}

The template for successful pleading of an antifraud claim based on assertions of trustworthy compliance systems prior to Omnicare Inc. was

22. See, e.g., Del. Code AnN. tit. $8, \S 102(\mathrm{~b})(7)(2015)$. 
Reese v. Malone. ${ }^{23}$ Following a series of oil spills and significant governmental enforcement actions for multiple violations of environmental laws, a securities class action was filed against British Petroleum (BP). Among the statements targeted in the suit was the representation in BP's 2005 Annual Report: "Management believes that the Group's activities are in compliance in all material respects with applicable environmental laws and regulations." In finding the statement false, the Ninth Circuit reasoned as follows:

Statements of legal compliance are pled with adequate falsity when documents detail specific violations of law that existed at the time the warranties were made ... Here, the complaint cites evidence of numerous violations, confirmed and alleged, of environmental laws and regulations, including: (1) the Clean Water Act, evidenced by BP's 2007 Guilty Plea with the DOJ; (2) Alaskan laws, evidenced by the company's civil settlement with the State; and (3) Pipeline Safety Laws, arising from BP-Alaska's failure to comply with [various Corrective Action Orders issued by regulators]. Based on these allegations-the validity of which were ultimately confirmed by the company's guilty plea, consent decree, and millions of dollars in fines and penalties-defendants cannot say that they were in compliance, in all material respects, with applicable environmental laws and regulations ...

The ... question is whether BP escapes possible liability by prefacing the statement with the phrase "management believes," and using the qualifier material compliance ...

A statement of belief is a "'factual' misstatement actionable under Section 10(b) if (1) the statement is not actually believed, (2) there is no reasonable basis for the belief, or (3) the speaker is aware of undisclosed facts tending seriously to undermine the statement's accuracy." Kaplan v. Rose, 49 F.3d 1363, 1375 (9th Cir. 1994) . . The mere fact of ongoing "discussions" with regulators is insufficient to create a belief in "material compliance" with the law. Here, the violations of environmental law were egregious-BP had just spilled over 200,000 gallons of oil onto the Alaskan tundra in violation of the Clean Water Act. Its corrosion monitoring and leak detection systems fell below industry standards and state requirements. And the discussions with regulators took place in the context of recent violations of the terms of the Corrective Action Order, imposed to mitigate "hazard[s] to life, property and the environment." Based on the pled facts, it is unclear how BP's management could consider the company to be "in compliance" or, alternatively, could view the violations to be immaterial.

For the foregoing reasons, we find that plaintiffs have adequately pled falsity. ${ }^{24}$

What appears most questionable with the Ninth Circuit's formulation is the bare allegation that BP did not believe its own opinion statement;

23. Reese v. Malone, 747 F.3d 557 (9th Cir. 2014).

24. Id. at $578-79$. 
Virginia Bankshares clearly rules out such a claim, unless objective evidence is introduced that supports the conclusion that the uttered opinion could not have been believed. On the other hand, Omnicare Inc. fully supports both of the remaining grounds because they each rest on a material misrepresentation being made in the form of a misstatement that there is a basis for the opinion and omission of material facts needed to render what was said to not be misleading, respectively.

While it may appear that Omnicare Inc. did not alter the formulation for judging claims of compliance from that illustrated in Reese, the Supreme Court's most recent treatment of opinion statements' indelible contribution is mandating close analysis of generalized statements of law compliance such as those in Reese and Citigroup. Prior to Omnicare Inc., reassuring claims of compliance were frequently dismissed as harmless puffery. For example, the Second Circuit dismissed claims based on J.P. Morgan's statement that it had "highly disciplined" risk management practices, reasoning J.P. Morgan's assertions were merely puffery. ${ }^{25}$ After Omnicare Inc., the generality of the claim gives way to whether management had a basis for the assertion and, if so, whether there was material information inconsistent with the claim that was not disclosed. Simply stated, a statement of compliance can be material despite being generalized and of the type investors would expect. So viewed, Omnicare Inc. qualifies substantially earlier jurisprudence dismissive of generalized optimistic expressions about management's stewardship. ${ }^{26}$ Another significant impact of Omnicare Inc. is that it relieves the plaintiff of the burden of alleging facts of knowing noncompliance with the law;27 after Omnicare Inc., the plaintiff can put into issue that the claim of compliance is baseless in light of pervasive violations, and hence porosity of the claimed compliance system. It remains to be seen to what extent Omnicare Inc.'s emphasis on resort to the half-truth framework will impact other areas.

In addition to recasting puffery as examined above, another potential area ripe for reconsideration is the "Bespeaks Caution" doctrine that

25. ECA Local 134 IBEW Joint Pension Trust of Chi. v. JP Morgan Chase Co., 553 F.3d 187, 206 (2d Cir. 2009).

26. See In re Ford Motor Co. Sec. Litig., 381 F.3d 563, 570-72 (6th Cir. 2004) (Ford is designing safety into its cars in suit based on nondisclosure of problems related to Bridgestone ATX tires on its Ford Explorer); Gusinsky v. Barclays PLC, 944 F. Supp. 2d 279, 288 (S.D.N.Y. 2013) (general statements of commitment to good corporate practices and maintaining internal controls not actionable where bank engaged in manipulating LIBOR rate used in its business); In re Marsh \& McLennan Companies, Inc. Sec. Litig., 501 F. Supp. 2d 452, 475 (S.D.N.Y. 2006) (statement that firm provided "independence of thought and objective advice" was mere puffery even though practices pursued were steering clients to vendors who rewarded the defendant with kickbacks); In re Kidder Peabody Sec. Litig., 10 F. Supp. 2d 398, 413 n.15 (S.D.N.Y. 1998) (defendant's reassurances regarding its culture, controls, and integrity were mere puffery in suit alleging pervasive scheme to increase profits by phantom trading in customer accounts).

27. See Kushner v. Beverly Enters., Inc., 317 F.3d 820, 831 (8th Cir. 2003) (despite pervasive double-recording of charges to Medicare patients suit based on assurances of trustworthy compliance program dismissed for failure to allege senior officers were aware of double billing scheme). 
protects forward looking statements. Outside the statutory safe harbor ${ }^{28}$ that protects knowingly false forecasts that are accompanied by meaningful cautionary language, courts have fairly consistently held that cautionary language is not meaningful if the defendant, when issuing a forwardlooking statement, is aware of material facts that are inconsistent with the forward-looking statement. ${ }^{29}$ This sensible result may well be extended to the statutory safe harbor on the reasoning of Omnicare Inc. that the known-undisclosed fact needed to be disclosed to prevent the cautionary language from itself being misleading. ${ }^{30}$

\section{CONCLUSION}

Investors assess firms on the basis of their future operations. The regulatory environment that defines their markets necessarily impacts firm costs and revenues and therefore can have a profound impact on any firm's financial performance and position. Management's statements regarding the firm's performance in light of regulatory strictures is necessarily important to investors and thus, a natural area for management to make disclosures to meet investor expectations. Omnicare Inc.'s focus on whether such statements misstate or omit material facts provides new vigor to assessing whether general statements of compliance with the law are misleading when actual practices are quite different.

To be sure, Omnicare Inc. does not provide the plaintiff with a frictionless glide path. The sine qua non for action is an affirmative statement of compliance. Inconclusive references to prevailing regulations, such as external regulations or internal codes of ethics, without express assurance of their being any reference to compliance will, as has occurred in the past,

28. Securities Exchange Act Section 21E, 15 U.S.C. $\$ 78 \mathrm{u}-5$ (2015).

29. See, e.g., Huddleston v. Herman \& MacLean, 640 F.2d 534, 544 (5th Cir. 1981), rev'd in part on other grounds, 459 U.S. 375 (1983) ("To warn that the untoward may occur when the event is contingent is prudent; to caution that it is only possible for the unfavorable events to happen when they have already occurred is deceit."); see also Franklin High Yield v. Cty. of Martin, 152 F.3d 736 (8th Cir. 1998) (professed uncertainty whether any shortfall would be addressed through entity's taxing authority misleading when it was known the municipality would not use its taxing authority); Kline v. First W. Gov't Sec., Inc., 24 F.3d 480 (3d Cir. 1994) (disclaimer in attorney's opinion does not protect against knowledge that facts on which such uncertainty could be based are materially different so that probable IRS treatment was known). However, most courts do not reach the same result when the forward looking statement is examined under the statutory safe harbor for forward looking statements. See Allan Horwich, Cleaning the Murky Safe Harbor for Forward-Looking Statements: An Inquiry Into Whether Actual Knowledge of Falsity Precludes The Meaningful Cautionary Statement Defense, 35 J. CorP. L. 519 (2010) (close analysis of extensive case law to conclude that cautionary statement renders the false statement immaterial).

30. This result can be seen as consistent with Congress's intent in creating a separate safe harbor for forward-looking statements accompanied by meaningful cautionary language as well as statements, not covered by such cautionary statements that were not made with knowledge of their falsity. As reasoned above, a reckless omission of a fact that prevented cautionary language from being meaningful would remain protected so that the twin safe harbors continue to exist. In contrast, a knowing omission of a fact necessary to understand the cautionary language would be actionable which appears consistent with the safe harbor that does not apply to knowing violations. 
not be sufficiently definitive to survive a motion to dismiss. ${ }^{31}$ Nonetheless, firm statements, such as those made by Omnicare are now to be assessed by their materiality so that the statement is actionable if there is no basis supporting the "we're clean" statement or facts exist that are materially necessary to qualify the statement.

Omnicare Inc.'s impact, however, is broad because Justice Kagan's opinion is not narrowly focused; her opinion is not anchored on opinion statements but rather on what is a misrepresentation. In so doing, she returns disclosure to its common law roots where materiality is guided by the objective standard of the reasonable investor. This orientation, as examined above, invites reconsideration of developments-opinion statements, puffery, and forward-looking statements-that have interpreted disclosure duties without considering the reasonable investor. It is now up to the lower courts to steer this new course in light of the compass provided by Omnicare Inc.

31. See Dailey v. Medlock, 551 Fed. App'x 841, 842, 846 (6th Cir. 2014) ("we are required by federal and state regulatory authorities to maintain adequate levels of capital to support our operations"); Desai v. Gen. Growth Props., Inc., 654 F. Supp. 2d 836, 857, 859 (N.D. Ill. 2009) (publishing code of ethics on website does not represent compliance with its provisions by officers); Andropolis v. Red Robin Gourmet Burgers, Inc., 505 F. Supp. 2d 662, 686 (D. Colo. 2007) (announcement of a new code of ethics not misleading even though there were contemporary breaches of the code that were not then disclosed). 